\title{
小児の日帰り全麻下鼓膜チューブ挿入術
}

\author{
鈴木 秀明・中塚 滋*・千葉 敏彦*・高坂 知節
}

\section{Tympanostomy Tube Insertion for Children under General Anesthesia in Day Surgery}

\author{
Hideaki Suzuki, Shigeru Nakatsuka, Toshihiko Chiba and Tomonori Takasaka \\ (Tohoku University School of Medicine)
}

\begin{abstract}
Twenty-three children with secretory otitis media, aged from 3 to 8 years, underwent tympanostomy tube insertion under general anesthesia in day surgery. The patients were anesthetized by inhalation of nitrous oxide and sevoflurane via face mask, and the surgery was done without hindrance in all the cases. Six patients manifested post-operative low grade fever, which was easily controlled with antifebrile medication. No major complications such as vomiting, aspiration, laryngospasm, pulmonary edema, atelectasis, prolonged apnea or delayed recovery were observed. We conclude that tympanostomy tube insertion under general anesthesia can be satisfactorily performed as day surgery. The advantages and disadvantages of day surgery in otolaryngology are discussed.
\end{abstract}

Key words : children, tympanostomy tube insertion, day surgery, mask anesthesia, general anesthesia

\section{はじめに}

鼓膜チューブ挿入術は基本的には数分間で終了する小 侵襲の手術であり，局所麻酔下に外来処置室で行われる ことが多い．しかし学童期以前の幼小児に対して行ら場 合には全身麻酔が必要となることが多く，この場合には 通常数日間の入院を要する.耳鼻咽喉科領域の全麻手術 を日帰り手術として行ら施設は本邦ではきわめて少数に 限られていて(12) 欧米とは異なり漂とんど普及していな いのが現状である． 3 歳児の耳科検診が始まって以来, 全麻下での鼓膜チューブ挿入術が必要となる症例がます ます増加してきているが，入院期間の短縮により患者や 家族への負担軽減が実現できれば有意義なことである.

さて，1981年に実用が開始されたセボフルレンは血液/ ガス分配係数が 0.6 と低く, 導入・覚醒が非常に速やか で3) 従来のハロセンやェンフルレンに取って代わりつつ
ある. 今回われわれは滲出性中耳炎の小児に対しセボフ ルレンによるマスク麻酔により日㷌り全麻鼓膜チューブ 挿入術を行い良好な結果を得たので，その日帰り手術の システムについて報告する.

\section{対象と方法}

対象は 3 歳から 8 歳, 平均 4.9 歳の 23 例で男 9 例, 女 14例である. その適応はティンパノグラムが両側ともに $\mathrm{B}$ タイプで鼓膜所見でも出液が $(+)$, 純音聴力検査で 両側とも $25 \sim 30 \mathrm{~dB}$ 以上のはっきりした難聴があり, そして患者または家族が難聴を訴える場合で, しかも 2 〜 3 力月の保存的治療を行っても改善せず, 外来処置室 で局麻下にチューブ挿入でさなかった症例に対して行っ た、ただし口蓋扁桃やアデノイドの著しい肥大がある場 合にはマスク麻酔の際に気道狭窄が起こり易く, また口 
蓋扁桃摘出，アデノトミーの適応ともなるため鼓膜チ ューブ挿入術単独では行わなかった.

外来受診時からの施行手順であるが，まず $2 \sim 3$ 週間 前に全麻検査を行い，このとき患者と家族への注意事項 を説明した(表 1 )。との中でも手術前夜10時以降経口摄 取を禁止することが麻酔中の事故を防止するために重要 であることを十分に強調した．紙おむつを持参，装着さ せるのは術中の円滑な流れ作業を中断させないための工 夫である．また当日帰宅できない可能性に関しても承諾 を得た。

さて当日の朝は 9 時に入院させ入院後ブドウ糖電解質 輸液を開始した。このとき上気道炎があったり術前指示 を守らず経口摂取をしてしまったような場合には中止と した．前投薬は 30 分前に硫酸アトロピンとアタラックス Pを筋注で投与し，手術は通常午後 1:30より開始した。 麻酔は笑気 $50 \%$ ，セボフルレン $1.5 \sim 2.5 \%$ をェースマ スクで吸入させて行った．鼓膜チューブ挿入術はホッチ
キス型耳鏡を用いて行い，鼓膜の前下象限に同心円状の 切開を置きューケンつば付きチューブを挿入した．その 後病室にて輸液扣よび抗生物質投与を行いながら経過を 観察し，午後 5 時に全身状態をチェックした後に退院帰 宅させ, 䚻宅後は通常通りの経口摄取を許可した. 翌日 より経口にてセフェム系抗生物質を 3 日間服用させ, 耳 痛, 耳漏, 発熱などの問題がなければ 1 週間後に再診し た. 退院時のチェックポイントとしては, (1)バイタルサ インが安定していること, (2)意識が清明であること, (3) 独り歩きができること, (4)嘔気, 嘔吐がなく経口摂取が 可能であることなどを必要条件とした.

\section{結果と考察}

表 2 亿実際の症例の手術時間, 麻酔時間, 覚醒時間を 示した. 手術時間は10〜20分のものが多く平均約 16 分, 麻酔時間は平均約 35 分, 覚醒に要する時間は一貫して安 定しており平均 10 分であった。この日帰り手術システム

表 1 患者と家族への注意事項

(1) 手術の前日は夜の 10 時以降、何も食事を掑らせないでください。飲物も禁止となり ます。当日も朝から食物も飲物も一切禁止です。麻酔中の嘔吐を防ぐために大切なことで すから必ず守ってください。

(2) 紙おむつを 1 個持参してください。

(3) 午前 9 時までに耳鼻科外来においでください。病室に御案内します。そして点滴を始 めます。

(4) 手術は午後 1：30より開始します。手術室に入る前に紙おむつを装用させてくださ い。

(5) 通常、当日の夕方 5 時までに退院できます。

〔6)帰宅後は吐き気がなければ普通に食事をさせて結構です。

(7) 入浴や水泳は翌日から耳栓をして行なってください。

８）退院時に3日分の薬をお渡ししますので、翌日から服薬させてください。

(9) 耳痛、耳だれ、発熱などがあれば翌日外来で診察しますが、順調であれば 1 週間後に 診察となります。

(10) 麻䣲のかかりやすさ、覚めやすさには個人差があり、当日退院できないこともありま すので御了承ください。 
表 2

\begin{tabular}{|c|c|c|c|c|}
\hline 症例 & 患側 & 手術時間（分） & 麻醉時間 (分) & 覚醒時間 (分) \\
\hline 6 歳 男 & 両 & 30 & 45 & 10 \\
\hline 4 歳 男 & 両 & 28 & 53 & 18 \\
\hline 4 墄 男 & 両 & 20 & 52 & 10 \\
\hline 4 墄女 & 左 & 18 & 30 & 3 \\
\hline 6 歳女 & 両 & 40 & 65 & 12 \\
\hline 3 墄女 & 両 & 9 & 30 & 12 \\
\hline 8 歳女 & 両 & 22 & 35 & 7 \\
\hline 4 墄女 & 両 & 15 & 30 & 8 \\
\hline 5歳女 & 両 & 14 & 28 & 11 \\
\hline 5歳男 & 右 & 7 & 36 & 15 \\
\hline 3 歳 男 & 両 & 15 & 20 & 3 \\
\hline 5 歳男 & 両 & 22 & 32 & 5 \\
\hline 4 歳女 & 両 & 16 & 35 & 10 \\
\hline 4 歳女 & 両 & 8 & 23 & 10 \\
\hline 3 歳 女 & 両 & 12 & 35 & 8 \\
\hline 6 歳男 & 両 & 11 & 30 & 9 \\
\hline 7 歳 男 & 両 & 7 & 30 & 17 \\
\hline 6歳女 & 両 & 5 & 25 & 10 \\
\hline 4歳 女 & 両 & 10 & 18 & 3 \\
\hline 6歳男 & 両 & 13 & 30 & 15 \\
\hline 6歳 女 & 左 & 5 & 25 & 10 \\
\hline 5歳女 & 両 & 14 & 40 & 12 \\
\hline 4 墄女 & 両 & 33 & 50 & 12 \\
\hline 平均 & & 16.3 & 34.7 & 10.0 \\
\hline
\end{tabular}

に执いて起こり得る合併症を挙げてみると，まず麻酔中 のものとして気道の狭窄, 閉塞が考えられ, その原因と しては, 吐物, 喉頭痤攣, 舌根沈下, 扁桃肥大, アデ, イド肥大などが挙げられる。吐物については経口摂取を 厳格に禁止するためほとんど起こり得ない。喉頭痤卛は 吐物, 挿管の刺激, 咽頭吸引時の刺激などが原因となっ て起こることが多いが，本方式ではこれらの要因が発生 する可能性が少ないため実際に起こっていない，麻醉中 の舌根沈下は高率に起こるが，フェースマスク拉よび下 顎の把持法に習熟することによって解消できた。 また口 蓋扁桃肥大, アデノイド肥大が存在する場合には気道狭 窄が起こり易いが，これらの症例は前述したよらにむし ろ口蓋扁桃摘出, アデノトミ一の適応とし, 本術式の適 応から除外した．以上のよらな気道狭窄，閉塞に関寸る 問題は1988年に開発されたラリンゲアルマスクを使用す
ることによってさらに改善される余地がある4).な招軽 度の自発呼吸抑制は必発であるが麻醉中は適宜補助呼吸 を行った。嘔吐, 誤燕は前に述べたように経口掑取の厳 格な禁止により防止できた。

次に麻酔後に発生し得る合併症であるが, 咳嗽, 咯痰 は挿管の刺激に起因することが多く，マスク麻酔では概 して軽度であった. 術後の発熱については23例中 6 例に 認められたが，いずれも $37^{\circ} \mathrm{C}$ 台前半の軽度のものであ り, 解熱剤を使用して解熱し, 帰宅させることが可能で あった. また, 嘔気, 嘔吐, 肺炎, 肺水腫などもなかっ た. 覚醒の遅延は長時間の麻醉後に特に起こり易いが, 本術式では麻酔時間が平均 35 分 (最少 18 分〜最長 65 分) と 短く, 静脈内麻酔薬の投与がないことやセボフルレンの 特性も加わって, 麻酔ガス停止から覚醒までに要した時 間は平均10分と非常に短かった。 また，筋弛緩剤を使用 
しなかったため呼吸抑制が遷延したような例も見られな かった．麻酔薬の特性といら点から見れば1992年にアメ リカで実用が開始されたデスフルレンは血液/ガス分配 係数が 0.4 と報告されて扣り，セボフルレンよりもさら に速やかな導入・覚醒が期待される3)。な怙今回は診療 システムの都合上開始時刻を午後1:30としたが，これを 午前中に行らことができれば術後の観察時間を長くとる ことができ安全性を高めることができると考兄られた。

さて日帰り手術の長所としてはまず，長時間特に夜間 病院に漁在することによる患者自身の精神的ストレスが 軽减できるといらことが挙げられる. 特に小児ではこの ことは重要であると考兄られる．家族（主に母親）の側か ら見ると付添いに要する労力が大幅に軽減される. 入院 に要する患者や家族の精神的負担や労力はたとえ一泊で あっても大きく，このことは特に小児において多大であ り，日帰り手術を導入することによりこれらの問題は劇 的に解消される.この点に関して言えば日帰り手術は単 なる入院期間の短縮ではないことを銘記すべきである. さらに医療費の節減については今後社会的にも要求が高 まってくるものと思われる5 が，本邦の現在の保険医療 システムでは入院日数が延びることによる経済的負担の 増加はさ注ど著明ではないと言わざるを得ない(67)。 ま た，院内感染の機会が減るといらことも長所の 1 つとな り, 今後このことは重要になってくると考兄られる.

一方，日帰り手術の問題点としては，まず，手術侵襲 そのものに基く術後の危険性が挙げられるが, 鼓膜チ ューブ挿入術のように多くが外来処置室で行われている ような小侵襲のものについては問題ないものと考えられ る11)。次に麻酔の合併症であるが，無挿管，静脈内麻醉 薬なしで筋弛緩剤も投与しない短時間の全麻の場合には 術後の回復は速やかである. 小児外科の領域ではこうし た麻醉による日帰り手術が既に行われて拉り5)6)，さら 飞導入時の静脈麻酔剤投与や気管内㨉管が行われた場合 にも当日の帰宅が必ずしも不可能ではないとされてい る5)。この点に関しては麻酔の担当医との十分な打ち合 わせが必要であることは言らまでもない。また，日帰り で大丈夫なのかといら患者や家族の側からの不安が出る 場合があるが事前の説明を徹底すれば解決できるものと 思われる.ただしこうした社会的な背景を考慮すると， 日帰り手術の導入初期の段階ではとの先進国である アメリカ8)などと同様な広い適応を採ることには無理が あり，例えば多少とも合併症のある患者は除外すべきだ
し ${ }^{899)}$, 扁摘・アデノトミーなどの出血の可能性の高い 術式は避けるべきであり27710), さらに鼻副鼻腔以外の気 道を操作するような手術は禁忌としたほらがよいだろ ら11)。また，入院と退院が同日では困るといった病院 事務や看護婦側からの苦情については説得や交渉が必要 であり，そしてさらに日鹵り手術のための新たな医療シ ステムの確立の必要性も考兄られ, 必ずしも現在の医療 体制の延長線上では実施することが困難かも知れない.

もともと耳鼻咽喉科領域では小侵襲の手術が多く, 従 来より局麻下の場合には日帰り手術が広く行われてき た ${ }^{10)}$ が，これを全麻手術，特に小児の全麻手術にまで 拡大寸ることはきわめて意義深い，そしてこらしたシス テムは小児外科領域では国内でも既に1970年代から行わ れ普及しつつあるといら現実がある6).前述したよらな 日㷌り手術の問題点はいずれも解決可能なものであり, 多くの長所を持つ日㷌り手術は今後耳鼻咽喉科領域に括 いても積極的に導入すべきものと考光る.

\section{まとめ}

參出性中耳炎の小児 23 症例に対しセボフルレンによる マスク麻酔により日㷌り全麻下鼓膜チューブ挿入術を行 い，全例に执いて円滑な手術操作をすることができた。 今回の日㷌り手術のシステムについて詳細を報告し, 長 所や合併症・問題点について考察した. 問題点はいずれ も解決可能であると考兄られた。

本論文の要旨は第73回日本耳鼻咽喉科学会宮城県地方部会 （1993年 9 月11日, 仙台市)に㨟いて口演した.

\section{文 献}

1）浜田慎二, 小林 謙, 石田祐子, 他 : Day Surgery による 鼓膜チュービングの管理. 耳喉頭頸 $63 ： 573 〜 575,1991$.

2) 神尾友和, 相原康孝: 神尾記念病院に批ける Day surgery の適応. JOHNS 8 : 1471 1473, 1992.

3 ) Ornstein E: The new volatile anesthetics. Anesthesiol Clin North Am $11:$ 707 728, 1993.

4) Pennant JH, Anaes FRC and White PF : The laryngeal mask airway ; its uses in anesthesiology. Anesthesiology $79: 144 \sim 163,1993$.

5 ）松本陽一, 村田 洋: 小児の日帰り手術の現状と将来展望. 臨外 $46: 55 \sim 60,1991$.

6 ）津川 力, 松本陽一, 木村 健: 小児外科飞和けるDay Surgery. 日本医事新報 $2908: 29 \sim 31,1980$. 
7 ）河西信勝：頭頸部外科におけるDay Surgery. 臨外 46 : 23〜26, 1991.

8 ) 広瀬輝夫 : 米国の外来外科手術数及び独立外来外科施設の. 激増. 日本医事新報 $3469: 101 \sim 102,1990$.

9 ) 牧野永城: Day Surgery の現状と問題点. 臨外 $46: 17 \sim 21$, 1991.

10）黄川田徹, 秋田茂樹, 加藤洋治 : 耳鼻咽喉科と Day surgery. JOHNS $8: 1475 \sim 1479,1992$.
11）山口 豊: 呼吸器外科に拈ける Day Surgery. 臨外 46 : $27 \sim 30,1991$.

$$
\left.\begin{array}{l}
\text { 原稿受付 : 平成 } 6 \text { 年 } 12 \text { 月 } 1 \text { 日 } \\
\text { 原稿採択 : 平成 } 6 \text { 年 } 12 \text { 月 } 28 \text { 日 } \\
\text { 別刷請求先 : 鈴木秀明 } \\
\text { T } 980 \text { 仙台市青葉区星陵町 } 1-1 \\
\text { 東北大学医学部耳鼻咽喉科学教室 }
\end{array}\right)
$$

